\title{
Diet of Western Slimy Salamander, Plethodon albagula (Caudata: Plethodontidae), from Two Mountain Ranges in Arkansas
}

Joseph Milanovich

Loyola University Chicago, jmilanovich@luc.edu

Stanley E. Trauth

Arkansas State University - Main Campus

Tanja McKay

Arkansas State University - Main Campus

Follow this and additional works at: https://ecommons.luc.edu/biology_facpubs

Part of the Biology Commons

\section{Recommended Citation}

Milanovich, J. R., Trauth, S. E., \& McKay, T. (2008). Diet of Western Slimy Salamander, Plethodon albagula (Caudata: Plethodontidae), from Two Mountain Ranges in Arkansas. Southeastern Naturalist, 7(2), 323-330.

This Article is brought to you for free and open access by the Faculty Publications and Other Works by Department at Loyola eCommons. It has been accepted for inclusion in Biology: Faculty Publications and Other Works by an authorized administrator of Loyola eCommons. For more information, please contact ecommons@luc.edu. c) (†) $\Theta$

This work is licensed under a Creative Commons Attribution-Noncommercial-No Derivative Works 3.0 License. (c) Humboldt Field Research Institute, 2008. 


\title{
Diet of Western Slimy Salamander, Plethodon albagula (Caudata: Plethodontidae), from Two Mountain Ranges in Arkansas
}

\author{
Joseph R. Milanovich ${ }^{1,2, *}$, Stanley E. Trauth', and Tanja McKay'
}

\begin{abstract}
We identified stomach contents of 80 Plethodon albagula (Western Slimy Salamander) from two mountain ranges in Arkansas (Ozark and Ouachita) to examine if regional differences in diet occur. Museum specimens from 1985 to 2005 were used from locations throughout each mountain range. Although a wide variety of prey were found in stomachs, Hymenoptera: Formicidae and Coleoptera: Carabidae were found to be the most important food items in the diet of P. albagula. Ants and beetles constituted $85 \%$ abundance of their total diet $(79.6 \%$ Ozark and $90.1 \%$ Ouachita) and $52.2 \%$ of their total biomass $(42.6 \%$ Ozark and $64.1 \%$ Ouachita). Seventy-eight and $87 \%$ of individuals examined from the Ozark and Ouachita Mountains, respectively, consumed ants $(65 \%$ total, $83 \%$ for animals with food items in their stomachs), whereas $55 \%$ in the Ozarks and $58 \%$ in the Ouachitas consumed at least one family of beetle. Occurrence and biomass of prey items that did not include ants and beetles showed $P$. albagula to be a euryphagic predator, with $9.7 \%$ of diet being comprised of other prey types $(27.3 \%$ biomass $)$. Furthermore, importance values indicate ants were the most important prey item for $P$. albagula in both the Ozark and Ouachita samples, with carabid beetles (Ozark) and all beetles (Ouachita) being second most important. Jaccard Index indicated Ozark and Ouachita specimens shared $80 \%$ similarity in diet. Our data suggest $P$. albagula in Arkansas have high dependence upon ants and beetles, yet appears to be an opportunistic and euryphagic predator.
\end{abstract}

\section{Introduction}

The Ozark and Ouachita Mountains of Arkansas are two distinct and dissimilar regions. The Ozark Mountains in northern Arkansas underwent a series of uplifting and eroding events, creating plateaus of horizontal layers consisting of sandstone, shale, and limestone. The Ouachita Mountains in southern Arkansas were formed by folding and faulting events, creating long parallel ridges consisting primarily of sandstone, shale, and chert (Smith et al. 1984). The Arkansas Valley is an intermediary zone between the two mountain ranges and acts as a natural separation of the two regions, which collectively are considered the Interior Highlands. One difference between these regions can be seen in flora and fauna. The Ozark Mountains are primarily oak-hickory forests and contain cave-dwelling vertebrate and invertebrate species (Robison and Allen 1995, Smith et al. 1984). In

\footnotetext{
'Department of Biological Sciences, Arkansas State University, PO Box 599, State University, AR 72467. ${ }^{2}$ Current address - Daniel B. Warnell School of Forestry and Natural Resources, University of Georgia, Athens, GA 30602. "Corresponding author -milanovichj@warnell.uga.edu.
} 
contrast, the Ouachita Mountains are dominated by oak-pine forest habitat and are much drier when compared to the Ozark Mountains. Both regions contain vertebrates and invertebrates endemic to Arkansas (Robison and Allen 1995), and the Ouachita region is home to three endemic salamander species not found in the Ozarks (Smith et al. 1984, Trauth et al. 2004). The disparity in habitat between these two regions led us to question if there are differences between diets of Plethodon that occur in both mountain ranges.

We examined Plethodon albagula Grobman (Western Slimy Salamander), a large woodland salamander common in parts of Texas and throughout the Interior Highlands of Arkansas, Oklahoma, and Missouri (Baird et al. 2006, Conant and Collins 1998, Trauth et al. 2004). Diet studies throughout North America have been performed on or included P. glutinosus Green (Slimy Salamander) (Britton 1981, Davidson 1956, Hamilton 1932, Jensen and Whiles 2000, Powders and Tietjen 1974), the sister species of P. albagula (Highton et al. 1989); however, few studies have examined the diet of P. albagula. Oliver (1967), Britton (1981), and Crowell (1981) conducted diet analysis on $P$. glutinosus (currently P. albagula) from central Texas and northwest Arkansas, but these studies were limited to specific localities and covered few counties of $P$. albagula's range. Our study investigated the diet of $P$. albagula across two ecoregions and covered the majority of its range. Our goal was to quantify gut contents of $P$. albagula, an abundant salamander within both the Ozark and Ouachita Mountains of Arkansas (Trauth et al. 2004), and assess differences between populations in the two ecoregions.

\section{Materials and Methods}

Using museum specimens from the Arkansas State University herpetological collection (ASUHC), we examined the stomach contents of $40 \mathrm{P}$. albagula from the Ozark Mountains and 40 individuals from the Ouachita Mountains. Collection dates ranged from 30 October 1985 to 17 September 2005 and were primarily during spring and fall months $(n=58$ in March, April, and May; $n=20$ in September, October, and November; and $n=2$ in December, January, and February). Samples represented the entire range of P. albagula in Arkansas and included 18 counties.

Salamanders were sacrificed using a $20 \%$ chloretone solution, fixed in $10 \%$ formalin, and stored in $70 \%$ ethanol within $48 \mathrm{~h}$ of capture (only specimens preserved by S.E. Trauth were used to minimize variability of preservation techniques). For each specimen, we measured snout-vent length (SVL) using a ruler, determined sex (when SVL $>50 \mathrm{~mm}$ ) by locating testes or ovaries, and recorded season of capture. Stomachs were dissected and placed in $70 \%$ ethanol until contents were identified. Gut contents were identified, if an entire organism or a head alone were present, to the lowest possible taxon (Triplehorn and Johnson 2005). Prey items were totaled for both the Ozark and Ouachita specimens to determine abundance (total number of prey) and frequency (number of animals which consumed each prey item) of prey. Biomass (volume of prey item) was estimated by measuring maximum width 
(widest lateral points) and length (widest anterior to posterior points) for some prey items using a dissection microscope. Volume $\left(\mathrm{mm}^{3}\right)$ was estimated as a cylinder using length as the axis and width as the diameter (Maerz et al. 2005). Whenever possible, volume was estimated for up to five individuals from each family, and a mean volume was used to calculate biomass. Due to the limited number of whole-body specimens for some prey families, biomass could not be estimated for eight families. Biomass estimates were used to assess the extent to which each prey item could be used for caloric intake.

To compare the importance of prey items between the two regions, importance values (Anderson and Mathis 1999, Powell et al. 1990) were calculated for each prey taxon where volume could be determined. Importance values $\left(I_{x}\right)$ were calculated using the equation:

$$
I_{x}=\left[\left(n_{x} / N\right)+\left(v_{x} / V\right)+\left(f_{x} / F\right)\right] / 3,
$$

where $n_{x}, v_{x}$, and $f_{x}$, are the number, volume, and frequency of prey item $\mathrm{x}$, and $N, V$, and $F$ are the summations of the number, volume, and frequency of all prey items, respectively. Importance values range between 1 and 0 and represent the relative importance of a single prey taxon in the entire diet. Jaccard's index of similarity (Jaccard 1912) was calculated between the Ozark and Ouachita diet samples. The Jaccard index (JI) produces a value in the form of a percentage, which represents the degree to which two samples are similar. JI values were calculated using the equation:

$$
\mathrm{JI}=j / r * 100,
$$

where $j$ is the number of taxa found in both samples, and $r$ is the number of taxa found in one sample or the other.

\section{Results}

For specimens examined, SVL ranged from 30 to $75 \mathrm{~mm}$ (mean $\pm \mathrm{SD}=58.9$ \pm 9.4 ). Ozark specimens ranged from 39 to $72 \mathrm{~mm} \mathrm{SVL}$ (mean $\pm \mathrm{SD}=59.3 \pm 7.2$ $\mathrm{mm}$ ), whereas Ouachita specimens ranged from 30 to $75 \mathrm{~mm} \mathrm{SVL}$ (mean $\pm \mathrm{SD}=$ $58.4 \pm 11.3$ ). The Ozark sample included 21 females, 14 males, and 5 juveniles; the Ouachita sample included 18 males, 14 females, and 8 juveniles. Seventeen specimens (21\%) had empty stomachs ( 8 Ozark, 9 Ouachita) and were omitted from further analysis.

In total, 538 prey items were identified (186 in Ozark and 352 in Ouachita samples) from 18 different prey taxa. Gut contents consisted primarily of hymenopteran and coleopteran prey, particularly ants of the subfamilies Myrmicinae and Formicinae (Fig. 1). Overall, ants comprised the majority of prey items in terms of abundance, frequency, and biomass (Fig. 1). Ants were found in $83 \%$ of stomachs that contained food items $(78 \%$ in Ozark and $88 \%$ in Ouachita). They accounted for $82 \%$ of abundance $(70 \%$ in Ozark and $88 \%$ in Ouachita) of prey items and $34 \%$ of total biomass. In both ecoregions, beetles were found to be the second-most frequently consumed prey (Fig. 1), with carabid beetles being the most frequent coleopteran prey item consumed. 
Ranked importance values indicated that ants were the dominant prey category for both the Ozark and Ouachita samples (Table 1). For the Ozark samples, the importance value for ants was about three times greater than the next-most important prey categories, carabid beetles and all beetles combined (Table 1). All other prey items were less important than both ants and beetles

(a)

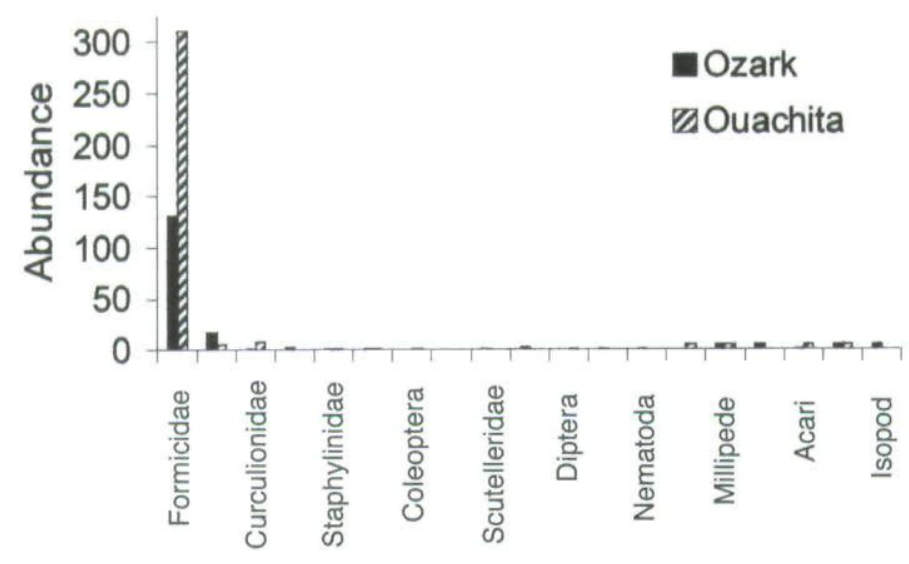

(b)

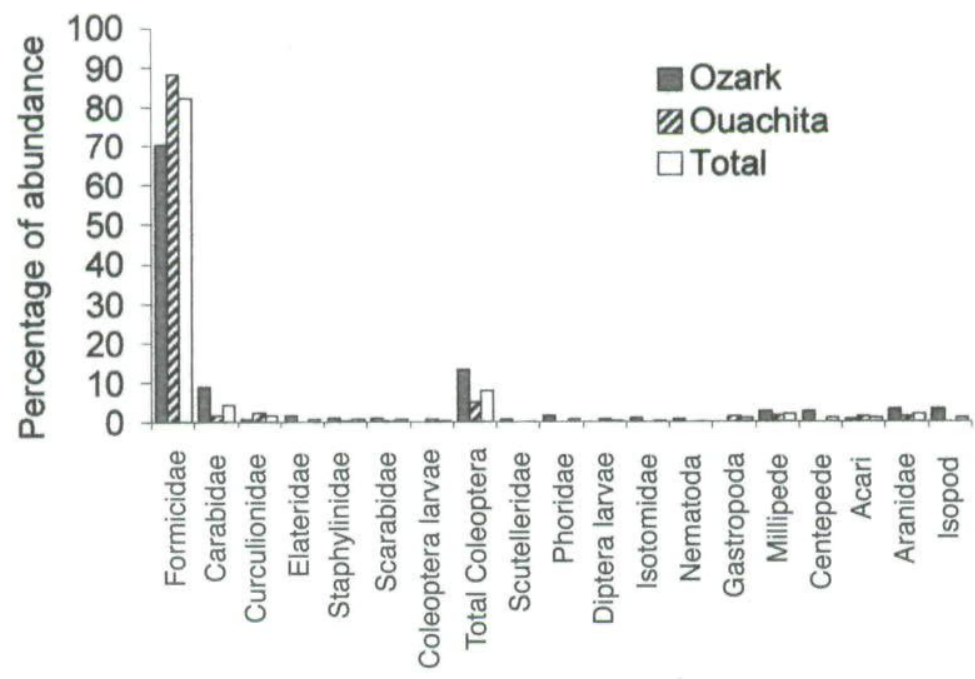

Figure 1 (above and opposite page). (a) Abundance, (b) percentage of total food items, and (c) percent of biomass of food items found in P. albagula stomachs (n $=32$ in Ozarks, $\mathrm{n}=31$ in Ouachitas). Individuals with empty stomachs were not included in analysis. 
(IV range from 0.008 to 0.07 ; Table 1). The importance value for ants in the Ouachita specimens was nearly five times greater than that for all beetles combined ( 0.14$)$. The Jaccard Index indicated an $80 \%$ similarity between diets of Ozark and Ouachita salamanders.

Table 1. Importance values (IV) for $P$. albagula in Arkansas. In parentheses, total number of prey, total volume of prey $(\mathrm{ml})$, and frequency of each prey type, respectively.

\begin{tabular}{|c|c|c|}
\hline Prey taxon & Ozark & Ouachita \\
\hline $\begin{array}{c}\text { Hymenoptera } \\
\text { Formicidae }\end{array}$ & $0.44(131 / 0.57 / 25)$ & $0.64(311 / 1.36 / 27)$ \\
\hline $\begin{array}{l}\text { Coleoptera } \\
\text { Total Coleoptera }\end{array}$ & $0.16(26 / 0.29 / 14)$ & $0.14(16 / 0.33 / 13)$ \\
\hline Carabidae & $0.18(17 / 0.79 / 11)$ & $0.07(6 / 0.28 / 5)$ \\
\hline Curculionidae & $0.008(1 / 0.01 / 1)$ & $0.05(8 / 0.05 / 6)$ \\
\hline Elateridae & $0.03(3 / 0.14 / 2)$ & $\begin{array}{l}- \\
-\end{array}$ \\
\hline Staphylinidae & $0.02(2 / 0.09 / 2)$ & $0.01(1 / 0.04 / 1)$ \\
\hline Scarabidae & $0.06(2 / 0.45 / 2)$ & $0.04(1 / 0.22 / 1)$ \\
\hline $\begin{array}{l}\text { Hemiptera } \\
\text { Scutelleridae }\end{array}$ & $0.03(1 / 0.18 / 1)$ & - \\
\hline Gastropoda & $\begin{array}{l}- \\
-\end{array}$ & $0.06(5 / 0.25 / 3)$ \\
\hline Diplopoda & $0.06(5 / 0.28 / 4)$ & $0.07(6 / 0.33 / 4)$ \\
\hline Chilopoda & $0.07(5 / 0.46 / 3)$ & $0.08(5 / 0.46 / 3)$ \\
\hline Araneae & $0.04(6 / 0.02 / 4)$ & $0.03(5 / 0.01 / 4)$ \\
\hline Isopoda & $0.05(6 / 0.21 / 2)$ & $0.01(2 / 0.08 / 2)$ \\
\hline
\end{tabular}

\section{(c)}

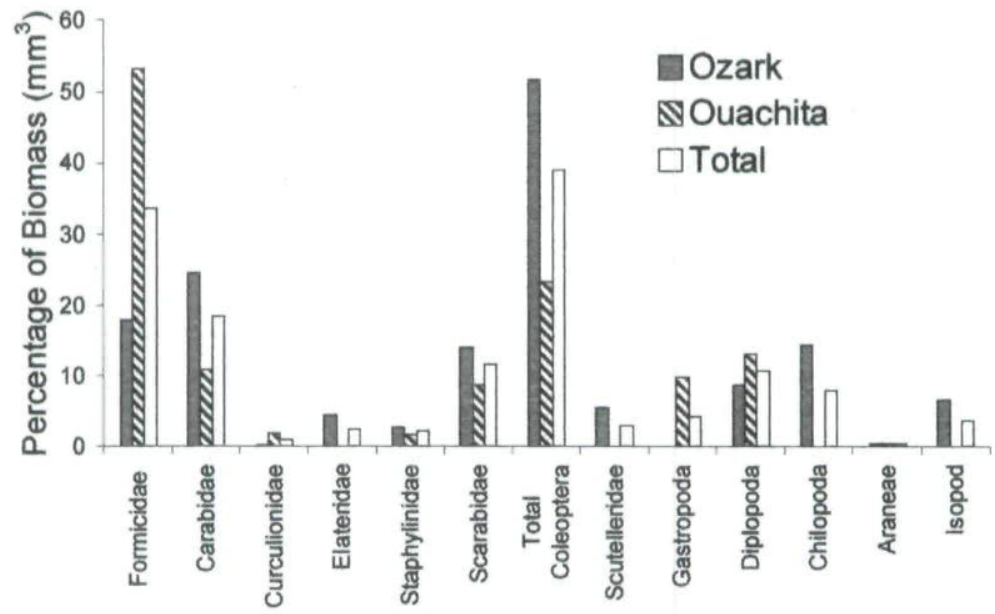

Food items 


\section{Discussion}

The euryphagic diet of P. albagula is consistent with other Plethodon, including $P$. glutinosus (in some regions currently P. albagula: Altig and Brodie 1971, Britton 1981, Crowell 1981, Davidson 1956, Hamilton 1932, Jensen and Whiles 2000, Oliver 1967, Powders and Tietjen 1974, Whitaker and Rubin 1971, Wilson and Larsen 1988). Although the importance of ants and beetles has been shown in Plethodon cinereus Green (Redback Salamander) (Hamilton 1932), Plethodon jordani metcalfi Brimley (Southern Greycheeked Salamander), Plethodon jordani shermani Stejneger (Red-legged Salamander) (Whitaker and Rubin 1971), and P. glutinosus (Britton 1981, Davidson 1956, Jensen and Whiles 2000, Pope 1950, Powders and Tietjen 1974), no prior study has found such a significant consumption of ants by Plethodon. For example, the next-highest frequency and abundance of ants found in any large Plethodon diet samples were found by Powders and Tietjen (1974) and Davidson (1956), respectively, for P. glutinosus. Remaining studies on large Plethodon show ants range from 2 to $80 \%$ by frequency and 1 to $37 \%$ by abundance (Altig and Brodie 1971, Crowell 1981, Jensen and Whiles 2000, Pope 1950, Powders and Tietjen 1974, Reagan 1972, Whitaker and Rubin 1971, Wilson and Larsen 1988). Britton (1981) found ants in nearly $80 \%$ of $P$. albagula (formerly P. glutinosus) stomachs from northwest Arkansas, but ants combined for only $38 \%$ of total prey items found in hillside specimens. Crowell (1981) found ants were 23\% (abundance) of all prey items and were found in $41 \%$ of the samples. Davidson (1956) found ants in $73 \%$ of $P$. glutinosus specimens, but they combined for only $42 \%$ of abundance.

With respect to beetles and other large Plethodon, frequency ranged from 13 to $80 \%$ and abundance from 5 to $26 \%$ (Altig and Brodie 1971, Crowell 1981, Jensen and Whiles 2000, Pope 1950, Powders and Tietjen 1974, Reagan 1972, Whitaker and Rubin 1971, Wilson and Larsen 1988). The highest abundance and frequency of beetles was found by Davidson (1956) for $P$. glutinosus and Oliver (1967) for $P$. g. albagula, respectively. Crowell (1981) found beetles in $80 \%$ of $P$. albagula stomachs, but they only amounted to $9 \%$ of total abundance, while Oliver (1967) found 64\% frequency and 39\% abundance of ants and $8 \%$ frequency and abundance for beetles in P. g. albagula. For $P$. albagula (formerly P. glutinosus) in Arkansas, Diptera were found to be more important than ants and beetles in other studies (38\% abundance, $57 \%$ frequency; Crowell 1981).

Our data show ants and beetles to be the most consumed prey of $P$. albagula across Arkansas. One possibility for our findings is a difference between time since capture and sacrifice between our study and others, as chitinous prey (such as ants and beetles) are likely to take longer to digest and thus can appear to be a more common prey in diet samples. In comparable studies this time period ranged from immediately to $12 \mathrm{~h}$ after capture, while in our study the majority of animals were sacrificed within $24 \mathrm{hrs}$, although they were kept cool up until death, which limits digestion considerably. 
The comparison of diet between the Ozark and Ouachita regions revealed differences in the importance of some individual taxa, but overall similarity of taxa preyed upon. Britton (1981) showed a relationship between availability of prey and prey selection in P. glutinosus (currently $P$. albagula) in Arkansas and found a disparity in diet composition between two different microhabitats. Plethodon glutinosus inhabiting hillside and seepage microhabitats fed on prey items that were found in higher abundance in those areas, suggesting this species is an opportunistic predator and highlighting differences in prey consumption among microhabitats. In this study, importance values confirmed the dominance of ants and beetles in the diet of $P$. albagula inhabiting both the Ozark and Ouachita Mountains. Ants were a more important prey item for salamanders inhabiting the Ouachita Mountains when compared to the Ozark Mountains. Overall, the importance of ants and beetles, and the similarity among importance values and regions $(\mathrm{JI}=80 \%)$ for the remaining prey items, was comparable for $P$. albagula across Arkansas. This indicates that regional differences in diet exist on a fine scale, but become less important as the range of investigation increases.

Our study revealed slight variations in diet between $P$. albagula from the Ozark and Ouachita mountain ranges in Arkansas; however, throughout much of its range, abundance, frequency, biomass, and importance of prey appear to be similar. Therefore, although variation in diet composition may exist for $P$. albagula among microhabitats, differences appear to be smaller as the scales increases. Specific microhabitat differences in prey selection by $P$. albagula, and possibly many large Plethodon, appear to combine on a larger scale to lessen specific differences.

\section{Acknowledgments}

We thank the many individuals who collected and deposited voucher specimens into ASUHC. Specimens were collected under the authority of the Arkansas Game and Fish Commission through scientific collection permits issued to S.E. Trauth

\section{Literature Cited}

Anderson, M.T., and A. Mathis. 1999. Diets of two sympatric neotropical salamanders, Bolitoglossa mexicana and $B$. rufescens, with notes on reproduction for $B$. rufescens. Journal of Herpetology 33:601-607.

Altig, R., and E.D. Brodie, Jr. 1971. Foods of Plethodon larselli, Plethodon dunni, and Ensatina eschscholtzi in the Columbia River Gorge, Multnomah County, Oregon. American Midland Naturalist 85:226-228.

Baird, A.B., J.K. Krejca, J.R. Reddell, C.E. Peden, M.J. Mahoney, and D.M. Hillis. 2006. Phylogeographic structure and color pattern variation among populations of Plethodon albagula on the Edwards Plateau of central Texas. Copeia 2006: $760-768$.

Britton, J.M. 1981. Microhabitat distribution and its effect on prey utilization in sympatric populations of Plethodon glutinosus and Plethodon dorsalis in northwestern Arkansas. Proceedings of the Arkansas Academy of Science 35:25-28.

Conant, R., and J.T. Collins. 1998. A Field Guide to Reptiles and Amphibians: Eastern and Central North America. Third Edition, expanded. Houghton Mifflin Company, Boston, MA. 616 pp. 
Crowell, R.L. 1981. Microhabitat selection and feeding ecology of troglophilic plethodontid salamanders in northwestern Arkansas. Ph.D. Dissertation. University of Arkansas, Fayetteville, AR. 208 pp.

Davidson, J.A. 1956. Notes on the food habits of the Slimy Salamander Plethodon glutinosus glutinosus. Herpetologica 12:129-132.

Hamilton, W.J., Jr. 1932. The food and feeding habits of some eastern salamanders. Copeia 1932:83-86.

Highton, R., G.C. Maha, and L.R. Maxson. 1989. Biochemical evolution in the slimy salamanders of the Plethodon glutinosus complex in the eastern United States. University of Illinois Biological Monographs 57:1-153.

Jaccard, P. 1912. The distribution of flora in the alpine zone. New Phytologist 11: $37-50$.

Jensen, J.B., and M.R. Whiles. 2000. Diets of sympatric Plethodon petraeus and Plethodon glutinosus. Journal of Elisha Mitchell Scientific Society 116: $245-250$.

Maerz, J.C., J.M. Karuzas, D.M. Madison, and B. Blossey. 2005. Introduced invertebrates are important prey for a generalist predator. Diversity and Distributions 11:83-90.

Oliver, G.V., Jr. 1967. Food habits of the White-throated Slimy Salamander in central Texas. Transactions of the Oklahoma Junior Academy of Science 1967: 500-503.

Pope, C.H. 1950. A statistical and ecological study of the salamander Plethodon yonahlossae. Bulletin of the Chicago Academy of Science 9:79-106.

Powell, R., J.S. Parmerlee, Jr., M.A. Rice, and D.D. Smith. 1990. Ecological observations of Hemidactylus brookii haitianus Meerwarth (Sauria: Gekkonidae) from Hispaniola. Caribbean Journal of Science 26:67-70.

Powders, V.N., and W.L. Tietjen. 1974. The comparative food habits of sympatric and allopatric salamanders, Plethodon glutinosus and Plethodon jordani in eastern Tennessee and adjacent areas. Herpetologica 30:167-175.

Reagan, D.P. 1972. Ecology and distribution of the Jemez Mountains Salamander, Plethodon neomexicanus. Copeia 1972:486-492.

Robison, H.W., and R.T. Allen. 1995. Only in Arkansas: A Study of the Endemic Plants and Animals of the State. University of Arkansas Press, Fayetteville, AR. 184 pp.

Smith, K.L., W.F. Pell, J.H. Rettig, R.H. Davis, and H.W. Robison. 1984. Arkansas's Natural Heritage. August House, Little Rock, AR. 116 pp.

Trauth, S.E., H.W. Robison, and M.V. Plummer. 2004. The Amphibians and Reptiles of Arkansas. University of Arkansas Press, Fayetteville, AR. 421 pp.

Triplehorn, C.A., and N.F. Johnson. 2005. Borror and Delong's Introduction to the Study of Insects. Seventh Edition. Thomson Brooks/Cole, Belmont, CA. 864 pp.

Whitaker, J.O, Jr., and D.C. Rubin. 1971. Food habits of Plethodon jordani metcalfi and Plethodon jordani shermani from North Carolina. Herpetologica 27:81-86.

Wilson, A.G., Jr., and J.H. Larsen, Jr. 1988. Activity and diet in seepage-dwelling Coeur d'Alene Salamanders (Plethodon vandykei idahoensis). Northwest Science 62:211-217. 
Copyright of Southeastern Naturalist is the property of Humboldt Field Research Institute and its content may not be copied or emailed to multiple sites or posted to a listserv without the copyright holder's express written permission. However, users may print, download, or email articles for individual use. 